\title{
REGIONÁLNY ROZVOJ OBCE BUDMERICE
}

\author{
Marcel Olša, Petra Hencelová
}

\begin{abstract}
The article is focused on the assessment of regional development of the Budmerice municipality. The municipality of Budmerice strives to meet the stated goals and visions of the Budmerice Strategy for 2014-2022 through project and activity implementation. Efficiently spent costs bring improvements in different spheres of the municipality. The municipality provides quality living conditions, high quality and affordable services and creates conditions for self-fulfillment of the population. The article uses examples of realized projects to identify the development of Budmerice municipality. The main research methods used include the analysis of Budmerice's strategic documents.
\end{abstract}

Keywords: municipality of Budmerice, municipality development, strategy of municipality development, priority areas

\section{Úvod}

Rozvoj v regiónoch uskutočňovaný prostredníctvom regionálnej politiky (Rajčáková, 2003) a vykonávaný $\mathrm{v}$ inštitúciách územnej pôsobnosti iniciuje predstavu o budúcom rozvoji, ktorým je snaha plnit' a dosahovat' výsledky pri najvyššom využití geografického, l'udského a ekonomického potenciálu. Rozvoj obcí by mal byt' v záujme dosiahnutia vyváženého udržatel’ného rozvoja územia pri rešpektovaní princípov regionálnej politiky.

Ciel’om článku je analýza a evalvácia súčasných prioritných oblastí rozvoja v rámci strategickej časti Programu hospodárskeho a sociálneho rozvoja obce Budmerice na obdobie rokov 2014 - 2022 a ich ciel'ov. Pre potreby naplnenia vízie rozvoja tejto obce bolo zhodnotených viacero konkrétnych projektov a realizačných aktivít, ktoré prispeli k rozvoju obce a jej atraktívnosti.

\section{Teoreticko-metodické východiská problematiky}

Pojmu regionálny rozvoj či regionálna politika je v posledných desat'ročiach venovaná značná pozornost'. Dimenzia regionálneho rozvoja je evidentná $\mathrm{v}$ rôznych aspektoch spoločnosti a zaznamenala zvýšený záujem odborníkov z mnohých vedeckých disciplín (Bašovský, Lauko, 1990, Rajčáková, 2005, Tvrdoň a kol., 1995). Z geografického ponímania možno pojem „regionálny rozvoj“ chápat' ako súbor vnútorných a vonkajších ekonomicko-sociálnych procesov pozitívne ovplyvňujúcich daný región, pričom nespôsobuje útlm samotnému 
regiónu a priaznivo vplýva na parametre faktorov rastu.

Podl'a zákona 539/2008 Z.z. o podpore regionálneho rozvoja možno regionálny rozvoj ponímat' ako „súbor sociálnych, hospodárskych, kultúrnych a environmentálnych procesov a vzt'ahov, ktoré prebiehajú v regióne a ktoré prispievajú $\mathrm{k}$ zvyšovaniu jeho konkurencieschopnosti, trvalému hospodárskemu rozvoju, sociálnemu rozvoju a územnému rozvoju a $\mathrm{k}$ vyrovnávaniu hospodárskych rozdielov a sociálnych rozdielov medzi regiónmi““.

Príspevok vychádza z Programu hospodárskeho a sociálneho rozvoja obce Budmerice na obdobie rokov 2014 - 2022 (d'alej PHSR obce Budmerice). PHSR obce predstavuje strednodobý programový dokument, vychádzajúci z podrobnej socioekonomickej analýzy a stanovuje smer d'alšieho rozvoja obce, ciele a prvoradé potreby a úlohy $\mathrm{v}$ zabezpečení všestranného rozvoja. PHSR obce Budmerice komplexne analyzuje a hodnotí východiskovú situáciu obce, ako aj možné riešenia jej budúceho rozvoja $v$ rámci Bratislavského samosprávneho kraja (d'alej BSK) podl'a dostupných zdrojov (PHSR obce Budmerice; rozpočet obce; Databáza slovenských firiem a organizácií - FINSTAT; Sčítanie obyvatel'ov, domov a bytov 2011 - SODB 2011; Štatistický úrad Slovenskej republiky - ŠÚ SR; ZŠ s MŠ Budmerice) a analýza ich plnení po vydaní PHSR obce Budmerice.

\section{Základné informácie o obci}

Obec Budmerice leží na západnom Slovensku. Patrí do Bratislavského kraja, do okresu Pezinok. Počet obyvatel'ov obce bol 2402 (31. 12. 2017, ŠÚ SR) a rozlohu $30,08 \mathrm{~km}^{2}$. V okrese Pezinok susedí obec Budmerice s piatimi obcami Štefanová, Častá, Dubová, Vištuk, Jablonec (mapa 1) a na východe, v okrese Trnava, s dvomi obcami - Ružindol a Borová. Svojou polohou inklinuje najmä k susednému mestu Modra a taktiež k okresnému mestu Pezinok a Trnava.

Z hladiska fyzickogeografickej polohy leží medzi Malými Karpatmi na západe a Trnavskou pahorkatinou na východe. Matematickú polohu stredu obce určujú súradnice $48^{\circ} 36^{\prime}$ s. g. š. a $17^{\circ} 41^{\prime}$ v. g. d. Severozápadnú čast' územia obce pokrýva Lindavský les, patriaci medzi najzachovalejšie lesné komplexy Trnavskej pahorkatiny. Územie je odvodňované potokom Gidra, ktorý v severnej časti územia umelým prívodom zásobuje vodnú nádrž Budmerice a vodnú nádrž Rybník Hájiček. Priemerná nadmorská výška v obci je 176 m n. m. (najvyššia nadmorská výška je $226 \mathrm{~m} \mathrm{n}$. m. v Lindave a najnižšia $180 \mathrm{~m} \mathrm{n}$. m. pri vodnej nádrži). Intravilán obce sa nachádza $\mathrm{v}$ jej centrálnej časti.

Hlavným zdrojom financovania obce Budmerice je obecný rozpočet, ktorý každoročne schval'uje najvyšší orgán obce - obecné zastupitel'stvo. Okrem neho využíva miestna samospráva na financovanie potrieb súvisiacich so správou a rozvojom obce rôzne mimorozpočtové zdroje, napr. štátny rozpočet (zdroje od Ministerstva práce, sociálnych vecí a rodiny SR, Ministerstva kultúry SR, 
Ministerstva pôdohospodárstva a rozvoja vidieka SR i BSK), rôzne neštátne fondy a nadácie (Západoslovenská energetika, Revia a i.) a v ostatnom období aj zdroje Európskej únie.

Mapa 1: Mikropoloha obce Budmerice v okrese Pezinok

Map 1: Microlocation of the Budmerice municipality in the district of Pezinok

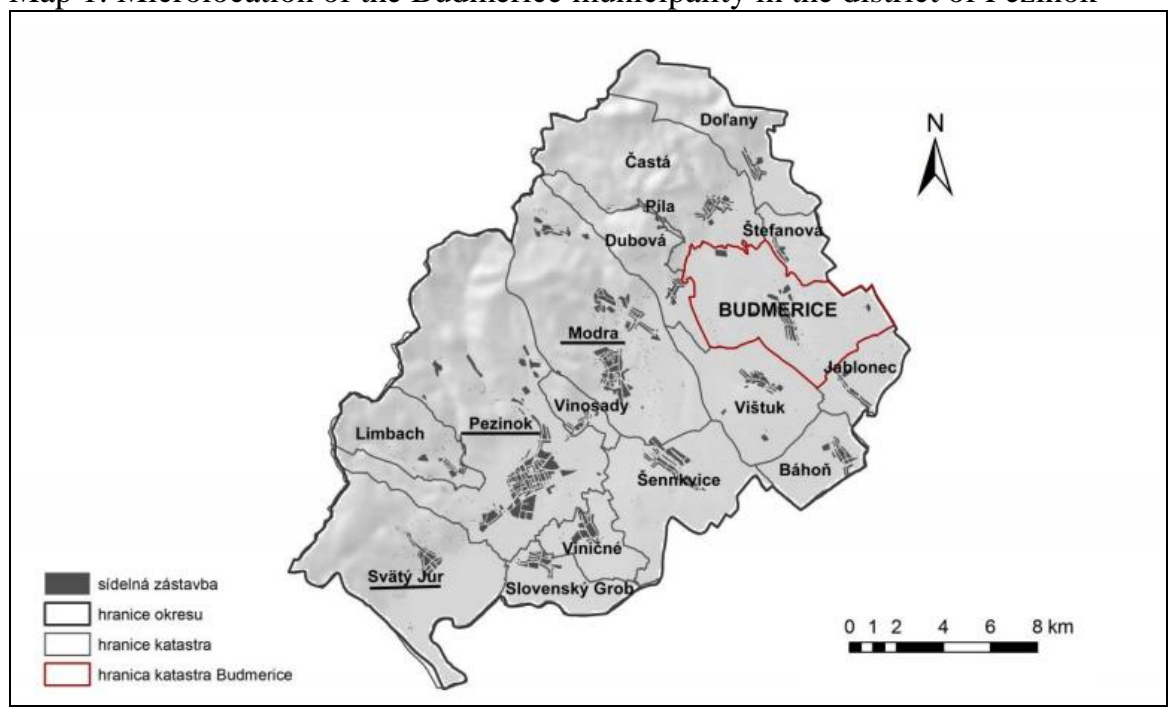

Zdroj: vlastné spracovanie

\section{Stratégia rozvoja obce}

Zhodnotením predchádzajúceho PHSR 2008 - 2013 s výhl'adom do roku 2015 možno poznamenat', že zrealizované projekty boli orientované na občiansku infraštruktúru, ekonomický alebo environmentálny rozvoj. Obec sústredila najväčšiu pozornost' $k$ naplneniu priorít, týkajúcich sa zvýšenia dostupnosti infraštruktúry, podpory kultúry a športu alebo výstavby bytov. Najvyššie finančné prostriedky a zároveň najviac projektov (pät') bolo vynaložených na naplnenie priority zvýšenia dostupnosti infraštruktúry a štyri projekty umožnili rozvoj obce v kultúrno-spoločenskej sfére.

Vízia súčasného PHSR obce Budmerice na obdobie rokov 2014 - 2022 znie nasledovne: „Obec bude príjemným miestom pre bývanie $\mathrm{s}$ dostupnými a kvalitnými službami, atraktívnym vzhl'adom a kvalitným životným prostredím $\mathrm{s}$ bohatým kultúrno-spoločenským životom." Pre naplnenie vízie boli stanovené tri prioritné oblasti - Prioritná oblast' 1: Kvalita bývania a dopravná infraštruktúra; Prioritná oblast' 2: Miestna ekonomika a služby; Prioritná oblast' 3: Atraktivita 
obce a život v nej (tab. 1). Zvýšenie kvality života obyvatel’ov v obci, konkurencieschopnosti a všestranného a vyváženého rozvoja obce v súlade $\mathrm{s}$ princípmi udržatel'ného rozvoja sa zabezpečí prostredníctvom jednotlivých opatrení, pre ktoré sú definované globálne ciele, napín̆ané prostredníctvom realizácie konkrétnych projektov a aktivít.

Tab. 1: Prioritné oblasti obce Budmerice na roky $2014-2022$

Table 1: Priority areas of Budmerice for the years $2014-2022$

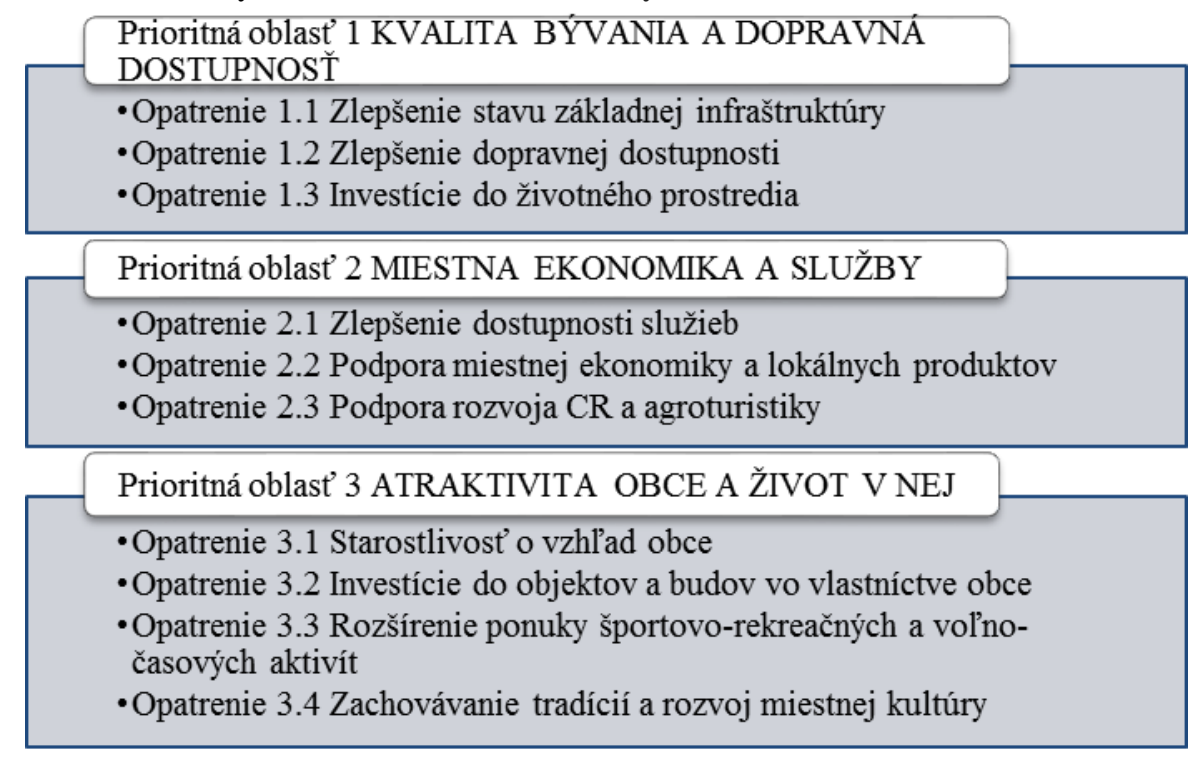

Zdroj: http://www.budmerice.sk/download_file_f.php?id=647468, upravené

\section{Prioritná oblast’ 1 - Kvalita bývania a dopravná infraštruktúra}

Globálnym ciel’om priority 1 je: „Zabezpečit' dobrý štandard pre bývanie obyvatel'ov v oblasti siet'ovej a dopravnej infraštruktúry a zlepšit' stav životného prostredia.“ (PHSR, 2015). Obec Budmerice sa zameriava aj na investície do tejto oblasti. Nakol'ko sa v obci nachádzajú staré, z dlhodobého hl'adiska neudržatel'né prvky technickej infraštruktúry, je potrebné zlepšit' stav občianskej vybavenosti. Dopravné spojenie autobusovou dopravou s okolitými obcami je v súčasnosti dostačujúce, čo sa týka spojenia s okresným mestom Pezinok a hlavným mestom Bratislava. V roku 2017 v obci vznikla cyklotrasa vedúca po ceste III. triedy. Vybudovanie cyklotrás a ich napojenie na existujúce cyklotrasy v okolí znamená pre obec príležitost' pre rast a rozvoj, zvýšenie dopravnej dostupnosti z okolitých obcí a miest a najmä zvýšenie povedomia o obci Budmerice. 


\section{Prioritná oblast’ 2 - Miestna ekonomika a služby}

Globálnym ciel'om priority 2 je: „Zvyšovat' ekonomickú sebestačnost' v obci $\mathrm{v}$ zabezpečovaní kvalitných a dostupných služieb a tovarov a podporou inovatívnych prístupov zvyšovat' konkurencieschopnost' malých a stredných podnikov v obci so zameraním na tradičné odvetvia.“ (PHSR, 2015).

Primárny sektor $\mathrm{v}$ obci je zastúpený Pol'nohospodárskym družstvom Budmerice a významnými pestovatel'mi hrozna, ktorí sú prevažne súkromne hospodáriacimi rol'níkmi. Pol'nohospodárske družstvo $\mathrm{v}$ Budmericiach bolo založené už v roku 1949, pričom funguje až do súčasnosti, kedy má 24 - 49 zamestnancov (FINSTAT, 2016). Opatrením na zvýšenie príjmov a s ním spojené zvýšenie stavu zamestnancov je podpísanie zmluvy o výsadbe a obhospodarovanie rýchlorastúcich drevín s nábytkárskou spoločnost’ou IKEA.

Tradičné odvetvia sú v obci zastúpené najmä v sekundárnom sektore. Podnikatel'ské subjekty zameriavajú svoju výrobu na spracovanie hrozna a produkciu kvalitných vín. Medzi najznámejšie vinárstva patrí rodina Čambalová, Spolok vinárov a fajnkoštérov alebo MM víno. Potenciál pre rozvoj cestovného ruchu podporuje obec zachovávaním tradícií vinohradníctva a vinárstva. Skvalitňovanie ponuky služieb sa realizuje usporadúvaním Budmerickej ochutnávky vín a aktívnou propagáciou produktov cestovného ruchu, ktorých je aj súčastou (Malokarpatská vínna cesta).

V terciárnom sektore prevádzkuje svoju činnost' prevažná čast' podnikatel'ských subjektov. Ekonomická sebestačnost' obce spočíva vo vytváraní zdravého podnikatel'ského prostredia. V obci sa nachádza pekárstvo, spracovanie mäsa a výrobu mäsových výrobkov, stavebníctvo, stolárstvo, nábytkárstvo, potravinárstvo a d’alšie. V obci sa nachádzajú dve predajne potravín, predajňa mäsa a mäsových výrobkov, stánok s ovocím a zeleninou, predajňa drogérie a rozličného tovaru. Okrem toho sa $\mathrm{v}$ obci nachádza aj tri stravovacie a štyri ubytovacie zariadenia (obecný penzión Lindava), tri hostince a jeden bar. K dispozícii sú aj služby holičstva, kaderníctva, pedikúra, manikúra, masáže, kozmetické služby, stavebno-obchodné činnosti, kvetinárstvo, pohrebné služby, kamenárstvo. V obci funguje zdravotné stredisko, v ktorom poskytuje svoje služby všeobecný lekár pre dospelých, praktický lekár pre deti a dorast, zubár a gynekológ. Ďalším významným subjektom je Základná škola s materskou školou Budmerice. Materskú školu navštevuje 88 detí a základnú školu 302 (ZŠ s MŠ, 2017). Škola zabezpečuje výučbu $\mathrm{v}$ oboch stupňoch vzdelávania, poskytuje aj mimoškolskú výchovu v záujmových krúžkoch a školskom klube. Priestory ZŠ s MŠ Budmerice však kapacitne nestačia a plánuje sa dostavba materskej školy (Schválený rozpočet obce Budmerice 2017 - 2019, 2016).

Ostatné služby obyvatel'om obce poskytujú zariadenia v Modre, Trnave, Pezinku alebo v Bratislave.

Snahou obce Budmerice je zapájanie do svojej ekonomickej činnosti výlučne podnikatel'ské subjekty so sídlom vobci. Na základe údajov o 
ekonomickej aktivite obyvatel'stva získaných prostredníctvom SODB 2011 možno konštatovat', že obyvatelia obce sú najväčším podielom zamestnaní vo verejnej správe, vel'koobchode a maloobchode. Aj napriek tomu, že sa v obci nachádza viacero významných podnikov, vel'ká čast' podnikatel'ských subjektov, ktoré v obci podnikajú, zamestnávajú značnú čast' obyvatel'ov z okolitých obcí a nie len obyvatel'ov Budmeríc. Najviac ekonomicky aktívnych podl'a veku je v obci 35 39 ročných (až 14,5 \% z EAO). Ekonomicky aktívne obyvatel'stvo (EAO) obce nachádza pracovné príležitosti aj v okolitých obciach, resp. v širšom okolí obce (Bratislava, Pezinok, Modra). Potvrdzuje to aj vysoká hodnota ukazovatela dochádzka do zamestnania (83,38 \%), získaná v rámci SODB 2011.

\section{Prioritná oblast' 3 - Atraktivita obce a život v nej}

Globálnym ciel’om priority 3 je: „Dosiahnut’ zlepšenie celkového vzhl’adu obce s dôrazom na zachovanie tradičnej architektúry a vytvorit' priestor a možnosti pre sebarealizáciu obyvatel'ov a na rozvoj kultúry v obci.“ (PHSR, 2015). Ide o zlepšenie vzhl'adu Budmeríc zachovaním vidieckeho rázu, obnovenie prírodného a kultúrneho dedičstva, zvel'ad'ovanie objektov a budov vo vlastníctve obce, aby sa zvýšila ich využitel'nost' a funkčnost', aby poskytovali kvalitnejšie služby pre obyvatel'ov.

$\mathrm{Na}$ začiatok roku 2018 obec pripravuje budovanie centrálnej zóny, konkrétne vysadením zelene, umiestnením mobiliáru a rekonštrukciou starého obecného domu na múzeum s gazdovským dvorom, ktorý má slúžit' na stretávanie sa obyvatel'ov a aj v rámci občianskych združení. Svoje využitie nájde aj ako zázemie obecnej kultúry a tradícií - hlavne vinárstva, mlynárstva a hrnčiarstva.

V obci Budmerice sa nachádza kaštiel' z konca 19. storočia, ktorý dal postavit' uhorský rod Pálffyovcov a dnes je vo vlastníctve Ministerstva kultúry SR. V rokoch 1946 a 1986 bol kaštiel' upravovaný a slúžil až do roku 2011 ako Dom slovenských spisovatel'ov za účelom rekreácie a na tvorivú činnost' slovenských umelcov. V roku 2014 - 2015 sa zrealizovala rozsiahla rekonštrukcia a po prvýkrát v histórii sa kaštiel' otvoril verejnosti v roku 2017 pod správou Slovenského národného múzea (d’alej SNM). V súčasnosti plní funkciu účelového zariadenia Ministerstva kultúry SR, čím sú prehliadky kaštiel'a verejnosti zastavané. Sprístupnený je len rozl'ahlý park. Napriek tomu obec podpísala zmluvu o prenájme exteriérových a interiérových priestorov kaštiel’a na organizáciu svadieb a iných obecných kultúrnych podujatí.

Ďalším ciel'om obce je podpora športových a iných vol'no-časových aktivít prostredníctvom vytvárania podmienok pre vyžitie sa obyvatel'ov. V Budmericiach pôsobí iba jedno súkromné centrum vol’ného času, ponúkajúce pre deti a mládež vel'ké spektrum záujmovej činnosti. Financované je z originálnych kompetencií v dotačnej schéme obce vo výške $14000 €$ ročne a poplatkov žiakov. Škola ponúka tiež viaceré možnosti vol'no-časových aktivít. Spolu sa tak vytvára široká škála možností trávenia vol'ného času detí. 
Obec podporuje aj aktivity rozvíjajúce kultúru a tradície obce, čím zabezpečuje rozvoj l’udského potenciálu, rozvoj sociálneho života v obci a sociálneho kapitálu (ubytovanie, strava, občerstvenie, suveníry, doprava a pod.). Popri komisii kultúry obecného úradu sa na organizovaní podujatí podielajú aj miestne neziskové organizácie. Medzi najväčšie podujatia s ohl'adom na rozvoj cestovného ruchu a rozvoj obce patria Celoslovenský divadelný festival Kasiopeafest, zapísaný v Knihe slovenských rekordov ako najväčší ochotnícky divadelný festival v počte účinkujúcich na Slovensku; Budmerická fazul'ovica gastronomická sút’až vo varení fazul'ovice spojená s finále celoslovenskej speváckej sút’aže Malokarpatský slávik; Budmerická ochutnávka vín a Krumplové šeličo, kedy členky Miestnej organizácie Matice slovenskej v Budmericiach vyrábajú zo zemiakov gastronomické špeciality.

Na rozvoji obce sa d'alej podiel'a komisia kultúry a športu obecného úradu spoločne so Slovenskou geografickou spoločnost'ou a OZ Camino Slovakia. Od roku 2017 spoločne budujú Svätojakubskú cestu do Santiaga de Compostela (smerové tabule, altánky, lavičky a i.) po existujúcom náučnom chodníku. Trasa cez obec (mapa 2) bola schválená predsedníctvom Camino Slovakia a jej oficiálne otvorenie sa plánuje v septembri 2018. Projekt bol podporený dotačnou schémou BSK.

Mapa 2: Trasa Camino cez obec Budmerice

Map 2: The Camino route through the Budmerice municipality

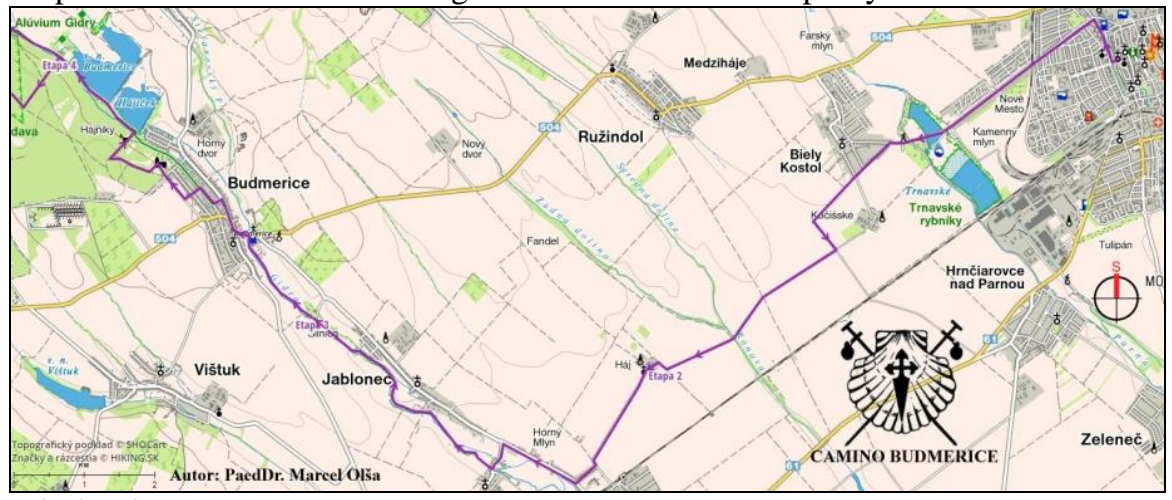

Zdroj: Olša, 2017

\section{Záver}

Uskutočňovanie regionálnej politiky podporuje rozvojové projekty. Ciel'om zákona Zákon NR SR č. 539/2008 Z. z. o podpore regionálneho rozvoja bolo vytvorenie komplexného systému regionálneho rozvoja na celoštátnej, regionálnej a miestnej úrovni. Obec Budmerice sa podiel'a na rozvoji na úrovni miestnej 
regionálneho rozvoja, pričom s okolitými obcami a partnerskými obcami spolupracuje pri realizácii rozvoja celého regiónu.

Príspevok je zameraný na pozitívny rozvoj obce v prioritných oblastiach, ich evalváciou a konkretizovaním projektov, ktoré sa od roku 2014 zrealizovali alebo sa nad'alej realizujú.

Obec Budmerice poskytuje svojim obyvatel'om vhodné a zdravé miesto na bývanie a pre návštevníkov obce príjemný pobyt. Obec kladie dôraz na zvyšovanie kvality občianskej vybavenosti a zelene. Vidiecka povaha so zachovaným kultúrnym a prírodným dedičstvom, spolu s príjemnou atmosférou spolužitia obyvatel’ov láka aj návštevníkov. Obec poskytuje kvalitné životné podmienky k bývaniu, zabezpečuje cenovo dostupné služby, vytvára podmienky pre sebarealizáciu obyvatel'stva. Aktívni obyvatelia sa podiel'ajú na živote v obci, rozvíjajú bohatý sociálno-kultúrny život a tradície.

Budmerice majú výhodnú dopravnú polohu vzhl’adom na blízku vzdialenost' okresných miest (Pezinok, Trnava). Z hl'adiska rozvoja cestovného ruchu sa obec v roku 2017 podiel'ala na vytvorení cyklotrasy a budovaní trasy svätojakubskej cesty cez obec, čo môže pozitívne ovplyvnit' cestovný ruch a zvýšit' povedomie o Budmericiach. Obec vytvára a rozvíja produkty cestovného ruchu (napr. divadelný festival - Kasiopeafest, gastronomické aktivity súvisiace s varením špecialít), a preto plní d’alšie ciele opatrení týkajúcich sa rozšírenia a podpory cestovného ruchu a spolupráce partnerstiev. V posledných rokoch obyvatelia obce a okolitého regiónu tak zaznamenávajú zvyšujúcu sa návštevnost' širokej verejnosti. Aktívni občania sa prostredníctvom občianskych združení a iných neziskových organizácií zameriavajú najmä na prosperitu sociálneho života a budovanie silnej väzby k obci. Vzhl’adom na bohatú históriu obce sa aktívne rozvíjajú tradície, sociálny a kultúrny kapitál a prispieva sa $\mathrm{k}$ atraktivite vzhl’adu obce.

Vedenie obce zabezpečuje zvyšovanie ekonomickej sebestačnosti, kvalitné a dostupné služby a tovary tým, že vytvára konkurenčné prostredie pre ekonomickú činnost' podnikatel'ských subjektov sídliacich vobci a mimo nej. Napriek tomu, že vidiecky typ obce, ako sú Budmerice, nemá možnost' poskytovat' pracovné príležitosti pre všetkých svojich obyvatel'ov, snaží sa podporou podnikania v obci zvýšit' počet pracovných miest, skvalitnit' a rozšírit' služby. V neposlednom rade sa pomocou podnikania snaží propagovat' a rozvíjat' cestovný ruch a zážitkovú turistiku, ked’že Budmerice majú pre tento rozvoj významné predpoklady a potenciál.

\section{Literatúra}

BAŠOVSKÝ, O. - LAUKO, V. 1990. Úvod do regionálnej geografie. Bratislava: SPN, 1990. $118 \mathrm{~s}$.

FINSTAT. 2017. Databáza slovenských firiem a organizácií. Dostupné na 
internete: <https://finstat.sk/databaza-firiem-organizacii> [cit. 15.10.2017] PROGRAM HOSPODÁRSKEHO ROZVOJA A SOCIÁLNEHO ROZVOJA OBCE BUDMERICE NA OBDOBIE ROKOV 2014 - 2022. 2015. Budmerice : Pro Implement, s.r.o., s. 119. Dostupné na internete: <http://www.budmerice.sk/download_file_f.php?id=647439> [cit. 15.10.2017] RAJČÁKOVÁ, E. 2003. Štrukturálna politika EÚ - jedna z možností rozvoja cestovného ruchu v Dolnohronskom mikroregióne. In Geografie XIV. Brno: Masarykova univerzita, 2003, s. 42-46. ISBN 80-210-3208-1.

RAJČÁKOVÁ, E. 2005. Regionálny rozvoj a regionálna politika. Bratislava: UK, 2005. 120 s. ISBN 80-223-2038-2.

SCHVÁLENÝ ROZPOČET OBCE BUDMERICE NA ROKY 2015 - 2017. 2016. Dostupné na internete: <http://www.budmerice.sk/schv-len-rozpo-tet-obcebudmerice-na-roky-2015-2017-2019.html> [cit. 15.10.2017]

SODB 2011. Sč́tanie obyvatelov, domov a bytov. Dostupné na internete: $<$ http://census2011.statistics.sk/> [cit. 15.10.2017]

ŠÚ SR. 2016. Štatistický úrad SR, Bratislava. Počet obyvatel'ov podl'a pohlavia podl'a obcí. DATAcube. Demografia a sociálne štatistiky. Dostupné na internete: <http://datacube.statistics.sk/\#!/view/sk/VBD_DEM/om7101rr/Po\% C4\%8Det\%20obyvate\%C4\%BEov\%20pod\%C4\%BEa\%20pohlavia\%20-\%20 obce\%20(ro\%C4\%8Dne)\%20\%5Bom7101rr\%5D/ > [cit. 15.10.2017]

TVRDOŇ, J. - HAMALOVÁ, M. - ŽÁRSKA, E. 1995. Regionálny rozvoj. Bratislava: Ekonomická univerzita, 1995. $174 \mathrm{~s}$.

ZÁKON č. 539/2008 Z. z. o podpore regionálneho rozvoja.

ZÁKLADNÁ ŠKOLA S MATERSKOU ŠKOLOU BUDMERICE. 2017. Dostupné na internete: <https://zsbudmerice.edupage.org/students/?> [cit. 15.09.2017]

\section{REGIONAL DEVELOPMENT OF BUDMERICE MUNICIPALITY}

\section{Summary}

Implementing a regional policy to create a framework for projects increases community development. Purpose of Act no. 539/2008 Coll. on the support of regional development was to create a comprehensive system of regional development at national, regional and local level. The municipality of Budmerice participates in the local level of regional development, working with neighboring municipalities and partner municipalities in the development of the region. The contribution is focused on the positive development of the municipality in the priority areas, their assessment and the realization of the projects that have been implemented or are being implemented since 2014.

The municipality of Budmerice provides its inhabitants with a suitable and healthy place to live and a pleasant stay for the visitors. The community 
emphasizes the emphasis on increasing the quality of civic amenities and greenery. Countryside nature with preserved cultural and natural heritage, together with the pleasant atmosphere associated with the coexistence of the inhabitants attracts the casual visitors of the municipality. The municipality provides quality living conditions for housing, provides affordable services, creates conditions for selffulfillment of the population. Active citizens participate in life in the municipality, develop rich socio-cultural life and traditions.

Budmerice has an advantageous transport position due to the close distance of the district (Pezinok, Trnava). From the point of view of tourism development, in 2017 the municipality participated in the creation of a cycling route and the construction of the Camino route, which could have a positive influence on Budmerice's tourism and awareness. The municipality develops and improves some tourism services (the Kasiopeafest theater festival, gastronomic activities related to cooking specialties) therefore fulfills other objectives of measures to expand and support tourism and partnership cooperation.

The management of the municipality ensures the increase of economic selfsufficiency, quality and accessible services and goods by creating a competitive environment for the economic activity of business entities based in and outside the municipality. Despite the fact that the rural type of municipality such as Budmerice does not have the potential to provide employment opportunities for all its inhabitants, it seeks to boost the number of jobs in the municipality, improve and expand services. Last but not least, with the help of entrepreneurship, they seek to promote and develop tourism and experience tourism, as Budmerice has important prerequisites and potential for this development.

In recent years, residents of the municipality and the surrounding region have been experiencing a rapid boom in cultural events in Budmerice, which have high traffic to the general public. Active citizens, through civic associations and other non-profit organizations, focus in particular on the prosperity of social life and the building of strong ties to the community. Due to the rich history of the municipality, traditions, social and cultural capital are actively developed and contribute to the attractiveness of the municipality.

\section{PaedDr. Marcel Olša}

Základná škola s materskou školou

Budmerice 430, 90086 Budmerice

E-mail: marcelolsa.geo@gmail.com

\section{Bc. Petra Hencelová}

Katedra regionálnej geografie, ochrany a plánovania krajiny

Prírodovedecká fakulta UK v Bratislave

Ilkovičova 6, 84215 Bratislava 4

E-mail: petra010203@gmail.com 